\title{
Geochemistry of quartz in the Tysfjord granitic pegmatites, northern Norway
}

\author{
DR. HAOYANG ZHOU ${ }^{1}$ AND AXEL MÜLLER ${ }^{1,2}$ \\ ${ }^{1}$ Natural History Museum, University of Oslo \\ ${ }^{2}$ Natural History Museum, London \\ Presenting Author: haoyang.zhou@nhm.uio.no
}

High-purity quartz (trace element contents $<50 \mathrm{ppm}$ ) is the raw material for the manufacture of high-tech products such as computer chips, optical fibers and solar panels. Although quartz is one of the most common minerals of the Earth's crust, highpurity quartz deposits are very rare, making it a critical raw material for the transition to a low-carbon and green society. The granitic pegmatites in Tysfjord, northern Norway have been known for their high-purity quartz reserves. These pegmatites are hosted in the metamorphosed Tysfjord granite and comprise two age groups, a Svecofennian and a Caledonian one. The former is associated with Svecofennian granitic magmatism, whereas the younger type is a product of partial melting related to Caledonian thrusting. Given the larger sizes, the Svecofennian pegmatites are of greater economic interest than the Caledonian counterparts are. However, the quartz geochemistry of the Tysfjord pegmatites has not been investigated systematically and thus genesis of such deposits remains poorly constrained, which motivates this study funded by the GREENPEG Horizon2020 project. Applying the in situ LA-ICP-MS analytical technique, we report the regional and internal distribution of quartz geochemistry in the Svecofennian and Caledonian pegmatites (a total of 30) and evaluate the effect of the Caledonian deformation on the quartz purity.

Our first results show that $\mathrm{Al}, \mathrm{Ti}, \mathrm{Li}$ and $\mathrm{Ge}$ dominate the chemical impurities in quartz. Quartz in all pegmatites is relatively homogenous, pure and has similar total trace element contents (Caledonian: $44 \pm 11$ ppm; Svecofennian: $48 \pm 19$ ppm). All data show a good correlation $\left(r^{2}=0.6\right)$ between $\mathrm{Li}$ and $\mathrm{Al}$, but $\mathrm{Ge}$ is richer in the Caledonian quartz. Quartz shows elevated $\mathrm{Ti}$ in those Svecofennian pegmatites that underwent stronger deformation, which we attribute to the higher deformation temperatures closer to the Caledonian base thrust. Interestingly, a handful of analyses show that quartz in the Tysfjord granite is remarkably purer $(23 \pm 17 \mathrm{ppm})$ due to its dramatic depletion in $\mathrm{Al}$ in contrast to quartz in the pegmatites. This implies that the Tysfjord granite is a potential target for high-purity quartz resources. 